\title{
Application of Solar Energies to Reinforce the Flow Water of Foggara in the Adrar Region
}

\author{
Abdelkader Harrouz** ${ }^{\ddagger}$ Omar Harrouz** \\ *Department of Hydrocarbon and Renewable Energy, Faculty of Science and Technology, Laboratory LDDI, Ahmed Draïa \\ University, (01000) BP 252, Adrar, Algeria \\ ** Institute of Natural Sciences and Agri-food Bordeaux (ISNAB), Bordeaux, France \\ Harrouz@univ-adrar.dz,harrouz@isnab.com \\ ${ }^{\ddagger}$ Corresponding Author: Abdelkader Harrouz, Ahmed Draïa University, Adrar, Algeria, Tel: +213664311537 , \\ Fax : +21349369456, harrouz@univ-adrar.dz
}

Received: 29.11.2018 Accepted: 19.12 .2018

\begin{abstract}
The Foggara in the region of Adrar is a traditional irrigation system constitute water acquisition and distribution processes, based on draining horizontal galleries. This traditional technique shows differences in the catchment source and the water-sharing technique. They capture the waters of the water table at the foot of a Jebel or the continental aquifer, a source of the Western erg great aquifer, drainage and infiltration, and finally, only the flood waters or drain the waters of the wades. In this work, we will use renewable energy as a local energy application for the assistance of this World Heritage used in the Adrar region. Our study will be applied on the site 'Amguid in Tamntiti'.
\end{abstract}

Keywords Renewable power, Solar, Wind, Management, Water pumping, Foggara,

\section{Introduction}

Global energy consumption is growing strongly in all regions of the world. It accounts for a large part of the vast use of fossil fuels (oil, natural gas, coal, etc.) that can be used to deplete these reserves and actually threaten the environment. This threat has manifested itself mainly through pollution and the global warming of the earth by the greenhouse effect [1-4].

For this reason, renewable energies appear today and in the long term as the adequate solution that covers this energy need by reducing the major disadvantage emitted by fossil fuels $[5,6]$. They have become an essential form of energy because of their flexibility, simplicity of use and the multiplicity of fields of activity. They offer the possibility of producing clean electricity and, above all, less dependence on resources, provided they accept their natural and sometimes random fluctuations [7,8].

As for our country: Algeria, the challenge of developing renewable energies is even more important. Indeed, these energies will increasingly cover the necessary and legitimate growth of basic energy services in the areas of rural development, housing, health, education and, in the long term, industry [9]. Solar photovoltaic energy is one of the important sources used in various fields such as water pumping that can be considered a promising application of this energy source [7, 9].

In the Saharan environment, water is available, but the vast majority is very little renewable, also vulnerable to pollution and especially the phenomenon of salinization Water resources and especially underground in the Saharan regions are most often poorly managed and impose rational and integrated management with a view to sustainability. Indeed, the management of water resources, especially underground in this vast and harsh territory, one of the hottest in the world, obeys rules specific to the Saharan regions, as is the case with the traditional systems of abstraction and control. Southern irrigation (Foggara) which testifies to a remarkable human hydraulic genius, whose organization is in the foreground [10]. It should be emphasized that in these regions, water is of such importance that it is the land that is the property of land at the expense of the land. Unfortunately, this traditional mode of catchment cannot meet the current water needs and in 
particular the prospects of development of agriculture, which result in the extension of new surfaces to be highlighted, as well as the improvement of the 'existing. The demand for water is already important and it will be even more, which would require modern and important means of capture (drilling, pump, etc.). Among the actions to be undertaken and likely to increase the flow of the Foggara is to strengthen the Foggara by some wells drilled in the downstream part of the gallery and that in order to increase by inflows of water the flow of the Foggara, without these wells influencing the stability of the hydrostatic level of the water table, whose origin of its supply comes from the upstream part. These downstream wells will be equipped with solar or wind energy pumps [11].

The Foggara is an underground pipeline built to feed the gardens in the palm groves, when it is not possible to dig wells [12]. It can have a development of 2 to 10 , even 15 kilometers. Pipes follow a slight slope (a few millimeters of elevation gain per meter) and run about 5 to 10 meters below the ground surface [12-14].

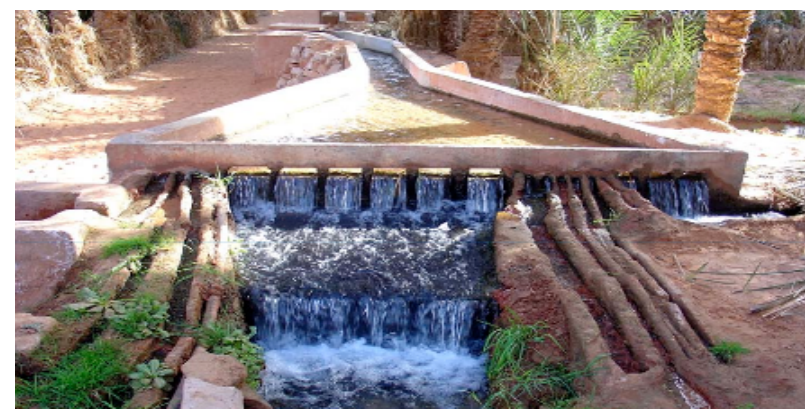

Fig. 1. The traditional groundwater system Foggara

Photovoltaic water pumping systems require only sufficient sun and a source of water, the need for reliable and continuous use of this energy for pumping water becomes a necessity during the last decade and the future. The cost of the photovoltaic pumping system (photovoltaic generator), the efficiency of the system which depends on the sun (direct coupled system especially) and the randomness of the load make photovoltaic pumping is not the most economical system in Algeria [10].

The main objective of this work is to make a presentation of renewable sources that exists in Algeria and to apply one of these sources to improve Foggara flow for traditional irrigation in our region of Adrar.

\section{Potential of Solar Energy in Algeria}

Algeria has one of the highest solar potentials in the world, estimated at 13.9 two per year [3]. Algeria has a great potential for solar energy. More than $2000000 \mathrm{~km}^{2}$ receive an annual exposure to the sun equivalent to 2500 Kwo $/ \mathrm{m}^{2}$ [12]. The sunstroke on almost the whole national territory exceeds the 2000 annual hours and can reach 3900 hours (high plains and Sahara). The daily energy obtained on a horizontal surface of $1 \mathrm{~m}^{2}$ is 5 Kwo over most of the national territory, about $1700 \mathrm{Kwo} / \mathrm{m}^{2} /$ year for the North and $2263 \mathrm{Kwo} / \mathrm{m}^{2} /$ year for the South of the country [3] such as illustrated in (Table 1 and Figure 2).

Table 1. Solar potential in Algeria [3]

\begin{tabular}{|c|c|c|c|}
\hline Places & $\begin{array}{c}\text { Coastal } \\
\text { area }\end{array}$ & $\begin{array}{c}\text { High } \\
\text { plateau }\end{array}$ & Sahara \\
\hline Surface & 4 & 10 & 86 \\
\hline $\begin{array}{c}\text { Average duration of } \\
\text { sunning(Hours/year) }\end{array}$ & 265 & 3000 & 3500 \\
\hline $\begin{array}{c}\text { Received average } \\
\text { energy(KWh/m²/year) }\end{array}$ & 1700 & 1900 & 2650 \\
\hline
\end{tabular}

Solar power has two main technologies: solar thermal and photovoltaic (PV gold). Solar thermal technology can provide heat and electrical energy Approximately 169, 440 Two.

Per year, equivalent to 5,000 times the current energy consumption in the country, can be used to support various applications. The potential for solar energy in Algeria is 60 times the current electricity consumption of the EU.
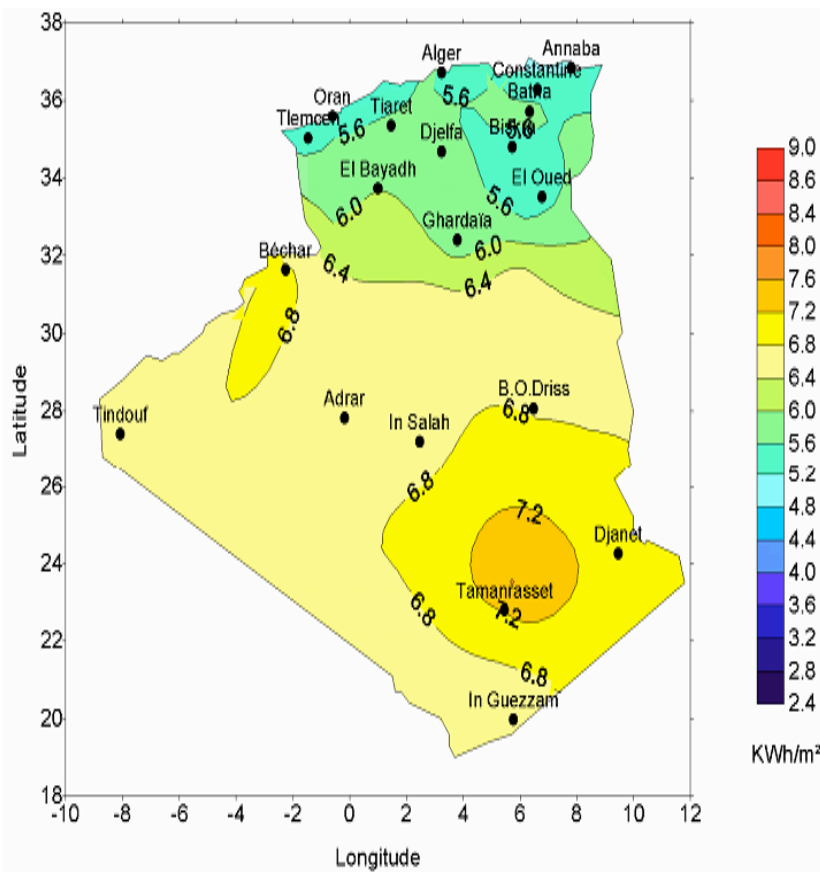

Fig. 2. Potential sites for solar electricity supply [13]. 
Algerian houses can install solar thermal systems to heat water through sensors. For the production of electricity, it is preferable to use concentrated solar technology to operate steam and gas turbines that drive electric generators [4].

Solar power plants (with several solar stations) can be used in the south of country where solar radiation is concentrated on the top of a tower from concentrating mirrors. With photovoltaic panels, solar radiation is directly converted into electricity. This technology is widely used around the world and is considered a well-developed and mature technology.

The estimation of PV capacity is at $40 \mathrm{THhr} /$ year and can be used in various places, like fixing small panels on the roofs of homes, large panels in schools, hospitals and supermarkets and installation of big photovoltaic installations.
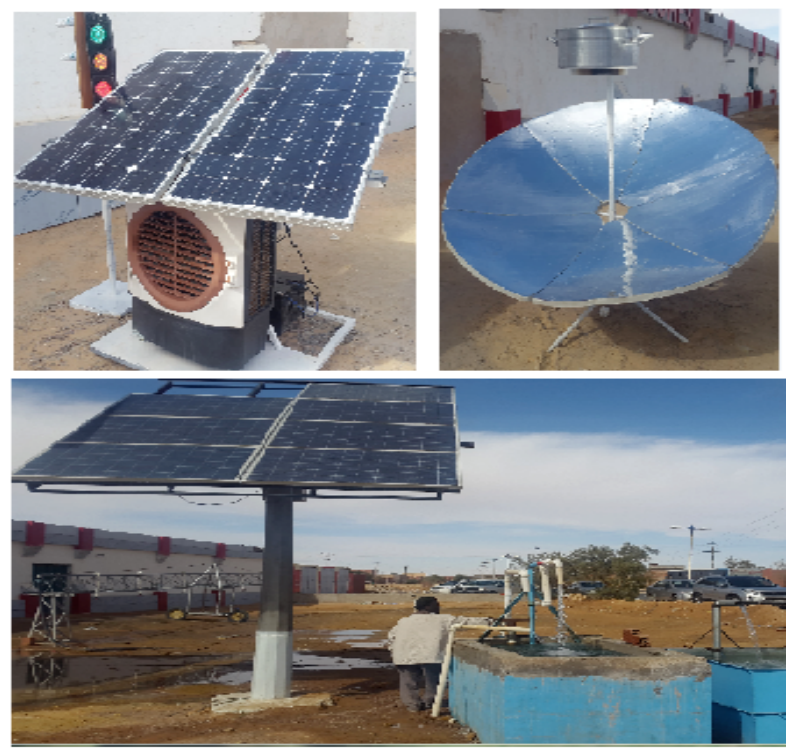

Fig. 3. Application of solar energy in Adrar.

General, different approaches technology for the utilization of solar energy will be assessed in the following section [4].

Photovoltaic solar is part of renewable energy. To harness this energy, we must design photovoltaic cells that convert light energy into electricity. This facility produces electricity that can be consumed locally by an individual or feed a distribution network (heat water or produce electricity). The networks can set up facilities like the Themis tower, it could reach $30 \%$ of solar energy converted into electricity thanks to gas and steam turbines. The energy is captured at the top of a tower at 1650 meters above sea level with mirrors and heliostats (adjustable mirrors) [16] like it show in the figure 4.

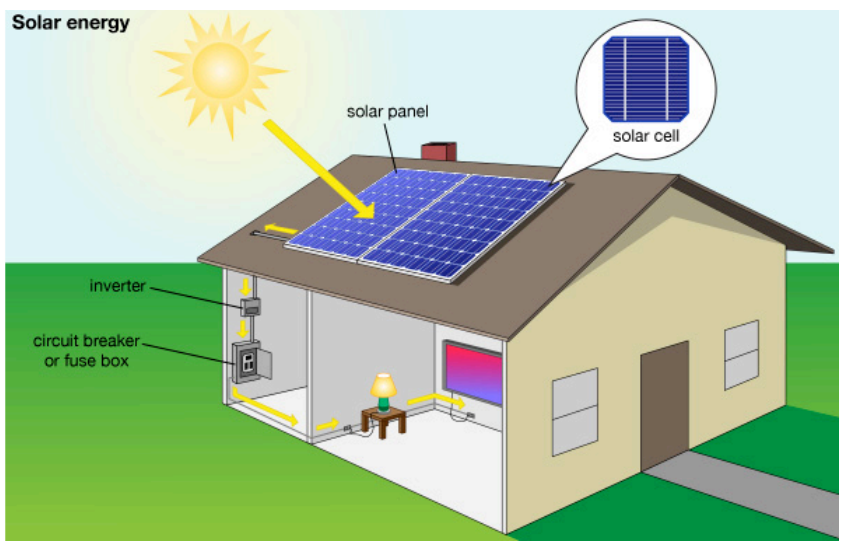

Fig. 4. Solar cell produce electricity [18].

In the coming years, the relatively limited needs of populations in southern Algeria, because of their low density, will be met. Future photovoltaic power plants will be located in the highlands region (Fig. 4). Like those currently in operation, these power stations serve to support the electricity grid in case of need, during the break of the day. The current form of exploitation of renewable energies in Algeria is highly centralized, the decentralized systems, which integrates the customer as consumer and producer are not topical.

In the heart of the Algerian Sahara, the wilaya of Adrar is located in the southwest of the country more than 1400 $\mathrm{km}$ from Algiers and its wilaya code is 01.It is located between the meridians: $2^{\circ} \mathrm{E}$ and $6^{\circ} \mathrm{W}$, and the parallels 20 $\circ$ and $32{ }^{\circ}$ North. Its total area is $427,968 \mathrm{~km} 2$ and Population 431,270 inhabitants, or about $18 \%$ of the total area of Algeria, almost a fifth of the national territory. Following the last administrative division of 1974, the wilaya of Adrar is composed of 11 dairas and 28 communes, and 294 ksars [8, 9]. The wilaya is divided into four regions from north to south: the Gourara, the Touat, the Tidikelt and Gourara.

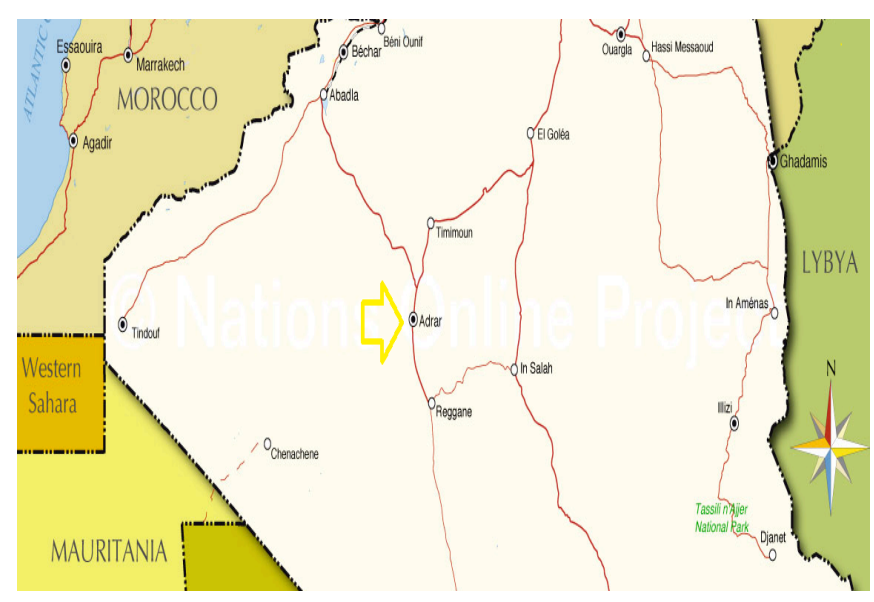

Fig. 5. The location of Adrar area [8] 


\section{Method of Reinforce the Flow Water of Foggara}

The study of all data Foggara is a national historical and cultural heritage. It is very adapted to the climatic and social conditions of the region of Adrar, but this technique is in a state of progressive degradation because of several factors of influence like: lack of maintenance, increase of the boreholes, and the drawdown of the water table to the regional scale...etc.

In this work, we will propose a local solution that improves the flow of Foggara water and uses renewable energy. The Foggara is composed of different parts:

* "An upstream part" that enters the water table, it is an active part (draining), it is the most important part of the Foggara.

* "A part downstream" that allows the flow of water to the gardens through its slope is the inactive part.

* "The permanent drainage" performed by the active part causes a continuous lowering of the water table and consequently a decrease in the flow rate and the evolution of the inactive part upstream.

* "The improvement of the flow" by the digging of the new wells allows the migration of the inactive part upstream and which results in the increase of the rates of the losses of the water drained in the downstream part by the infiltration especially if There is an obstacle that hinders the free flow of water.

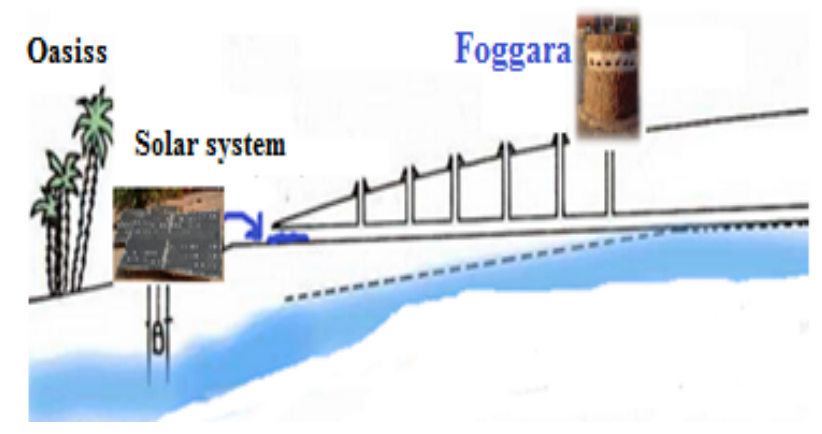

Fig. 6. The proposed solution to help Foggara.

In general, the wells and the gallery are not inside the sheet for to drain the water contrary to the case where the gallery is located inside the tablecloth, which this trench call useful part of the Foggara. According to the topography of the region, Foggara is used to transport groundwater gravitationally captured to land to irrigate (towards depression), whose natural level of ground level is lower than the piezometric level of the water table. The realization of the gallery is carried out beginning with the draining part or the so-called useful part.

Then we move to the executions of the then, one by one with a distance between axis equal to $15 \mathrm{~m}$ maximum and the realization of the channel depends on the nature of the ground with a width equal to $60 \mathrm{~cm}$ in most cases $(20 \mathrm{~cm}$ in the case of rocky terrain). In the end we connect the next neighbor by an underground channel made by hand, the latter allow even the passage of workers in case of nonrocky soil. As soon as the gallery reaches the free surface, water will be channeled to the pines inside the oases (Figure 6) [5]. Our goal in this work is to apply a renewable system to improve and safeguard the flow of these Foggara $[5,6$, 7].

\section{Results and discussion}

To turn the focus of our work, we have doing our experience in the site Amguid. The system consists of 4 amorphous solar panels connected with a pump immersed in a well of $46 \mathrm{~m}$.
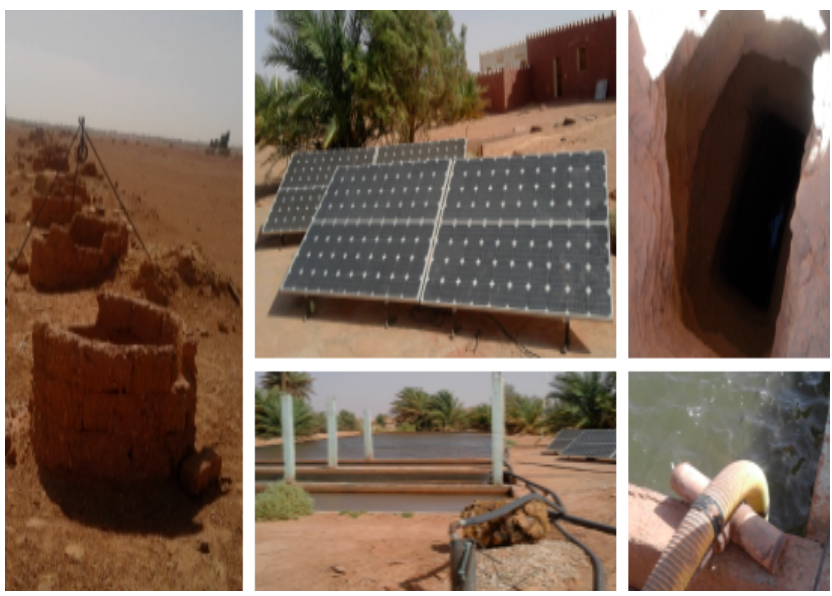

Fig. 7. The complete system of Foggara reinforcement.

The flow calculation results of the standard gauge pump is $\mathrm{Q}=0.78 \mathrm{~L} / \mathrm{s}$. The flow of Foggara before use of solar system:

TABLE 1. Foggara flow before reinforcement

\begin{tabular}{ccccc}
\hline Ranges & Abscises & Profound & $\begin{array}{c}\text { Nbrs } \\
\text { tours }\end{array}$ & Time \\
\hline 30 & 0 & 15 & 0 & \\
& 10 & 28 & 0 & 15 \\
& 10 & 0 & 10 \\
& 3 & & 17 \\
& 28 & 0 & 10 \\
& & 3 & 0 & 10 \\
& 40 & 10 & 0 & \\
& 40 & 3 & 0 & 10 \\
& & & & \\
& 48 & &
\end{tabular}


TABLE 2. Foggara flow after reinforcement

\begin{tabular}{ccccc}
\hline Ranges & Abscises & Profound & $\begin{array}{c}\text { Nbrs } \\
\text { tours }\end{array}$ & Time \\
\hline 15 & 0 & 15 & 0 & \\
& 15 & 15 & 0 & \\
& & 14 & 0 & 15 \\
& 25 & 15 & 0 & 10 \\
& & 14 & 0 & 17 \\
& 45 & 15 & 0 & 10 \\
& & 14 & 0 & 10 \\
& & 3 & & \\
& 49 & & &
\end{tabular}

\section{Discussion}

From the results of two tables 1 and 2, we can see that the Foggara flow rate after using a solar system that equals $0.8 \mathrm{~L} / \mathrm{s}$ is increased after the photovoltaic system has been reinforced up to $1.8 \mathrm{~L} / \mathrm{s}$. This result shows the effectiveness of the method used for sustainable and reasoned management of water.

\section{Conclusion}

Renewable energies are energy sources that renew themselves quickly enough to be considered inexhaustible on a human scale. They allow a decentralized production of electricity, can contribute to solve the problem of the electrification of the isolated sites where a large number of individuals is devoid of any energetic supply, thus being unable to satisfy any even minimal need and to improve its conditions of life. Using universal energy sources that require minimal maintenance, the solar solution is often the ideal economic and technological choice for the Adrar region or isolated installations.

Assessment of the use of Foggara and/or drilling in the region is perceived differently depending on the socioeconomic conditions and the type of water consumption, towards traditional agriculture (Ksours) or recent development. Indeed, the Foggara offers a water permanent by gravity that is to say without pumping (free) and without irrigation equipment unlike drilling. The latter requires in this type of area (free water table) for the drainage of water, the pumping system fossil fuels.

In this paper, we have shown that renewable energy can be applied for the protection of tradionnal Foggara irrigation system in the Adrar region. The applied solar system is very efficient for the increase of flow. It remains for the authority of the region to make Sustainable and reasoned management of water; Share, stop unauthorized drilling and use new energies for Foggara help.

\section{References}

[1] A. Harrouz. "Renewable Energy in Algeria and Energy Management Systems". International Journal of Smart Grids, ijSmartGrid, Vol. 2, N. 1, March, p. 34-39, mar. 2018. ISSN 2602-439X

[2] Benahmed Khelifa , Smahi Abla, Hireche Samia, "Smart Grid in Algeria: Ambition Towards a Great Expectation (international Conference on Information Technology for Organization Development) 2014.

[3] A. Harrouz, A. Benatialah and O. Harrouz," Direct Power Control of a PMSG Dedicated to Standalone Wind Energy Systems», Journal "IEEE Xplore, "Eighth International Conference and Exhibition on Ecological Vehicles and Renewable Energy", March 27-30, 2013, Monaco, France, 2013.

[4] A. Harrouz, A. Benatiallah, O. Harrouz, "Modeling of small wind energy based of PMSG in south of Algeria", Journal "IEEE Explore" of 2nd International Symposium on Environment-Friendly Energies and Applications(EFEA2012);10.1109/EFEA.2012.629404 2, pp.191 - 195, 2012, University Northumbrie, UK.

[5] N. Kasbadji Merzouk ; ' Quel avenir pour l'Énergie Éolienne en Algérie ?'. Bul. Ene. Ren, CDER, N¹4, p.6-7, 2008.

[6] O. Harrouz, A.P. Caricato, F. Romano. (2000, October 25-28). Optical properties of ITO/TiO 2 single and double layer thin films deposited by RPLAD, Proceedings of the International Conference WATRAMA, Tunis, pp.40-45.

[7] Servat H., Ga1llard B. (2000). Le SAGE nappes profondes de la Gironde. La Houille Blanche $\mathrm{N}^{\circ} 7 / 8$ 2000, pp.127-130.

[8] O. Harrouz, B. Brémond, M. Habi, A. Harrouz, "Modèle De Simplification Des Réseaux D'eau Potable", arhyss Journal, ISSN: 1112-3680, n³0, Juin 2017, pp. 253-272

[9] Grissac B. (2003). Réduction des prélèvements dans les nappes profondes de Gironde par maîtrise des usages de l'eau et substitutions de ressources. La Houille Blanche $N^{\circ} 3-2003$, pp.69-72.

[10] A. Hadj Arab, F. Chenlo, K. Mukadam and J.L. Balenzategui. (1999). Performance of PV Water Pumping Systems. Renewable Energy, 18, 191-204.

[11] A. Benatiallah, A. Mouly Ali, F. Abidi, D. Benatiallah, A. Harrouz and I. Mansouri, "Experimental Study of Dust Effect in Mult-Crystal PV Solar Module", International Journal of Multidisciplinary Sciences and Engineering (IJMSE), Volume 3, Issue 3, March 2012.

[12] I. Narvarte, E. Lorenzo and E. Caamaño. (2000). PV Pumping Analytical Design and Characteristics of Boreholes, Solar Energy, 68, 49-56. 
[13] A. Hamidat. (1999). Simulation of the Performance and Cost Calculations of the Surface Pump, Renewable Energy, 18, 383-392.

[14] A. Harrouz, A. Dahbi, O. Harrouz, A. Benatiallah, "Control of Wind Turbine based of PMSG Connected to Water Pumping System in South of Algeria", Journal "IEEE Xplore" of The 3rd International Symposium on Environmental Friendly Energies and Applications (EFEA), E-ISBN : 978-1-4673-2910-1, 19-21 Nov. 2014, Paris, France, pp. 48-52.

[15] A. Harrouz, I Daouali, K Kayisli, HI Bulbul, I Colak, 'Comparative Study between CSP and CPV as Two Energy Systems', Journal "IEEE Explore" of 7th International Conference on Renewable Energy Research and Application (ICRERA2018), Paris, 2018.

[16] A. Harrouz, K Nourdine, K Kayisli, HI Bulbul, I Colak, A Fuzzy Controller for Stabilization of Asynchronous Machine', Journal "IEEE Explore" of 7th International Conference on Renewable Energy Research and Application (ICRERA2018), Paris, 2018.

[17] A. Harrouz, "Metrology and Research of Measurement Error", Journal "IEEE Xplore"' of the 8th International Conference on Modelling, Identification and Control (ICMIC'2016), 15-17 November 2016, Algiers, Algeria.

[18]H. Glaoui, A. Harrouz, I. Messaoudi, H. Saab, "Modelling of Wind Energy on Isolated Area", International Journal of Power Electronics and Drive System (IJPEDS), ISSN: 2088-8694, Vol. (4) No.2, JUIN 2014, pp. 274-280. 